\title{
Synthesis, Characterization and Antimicrobial Activity of Abelia grandiflora Assisted AgNPs
}

\author{
Gaurav Sharma1, Nakuleshwar Dut Jasuja1*, Rajgovind ${ }^{1}$, Prerna Singhal ${ }^{1}$ and Suresh C Joshi ${ }^{2}$ \\ ${ }^{1}$ School of Sciences, Suresh Gyan Vihar University, Jaipur, Rajasthan, India \\ ${ }^{2}$ Reproductive Toxicology Unit, Center for Advanced Studies, Department of Zoology, University of Rajasthan, Jaipur, India
}

\begin{abstract}
In past few years, wide applicability of silver nanoparticles (AgNPs) in various field attract for an approach of rapid, cost effective and eco-friendly synthesis of AgNPs that is expanding research toward biological methods. The biosynthesised AgNPs were confirmed visually by appearance of dark brown color formation in mixture and silver surface plasmon resonance band observed at $413 \mathrm{~nm}$ by using UV-Visible Spectroscopy. The micrograph obtained by SEM and TEM confirmed the formation of AgNPs of $10-30 \mathrm{~nm}$ range. The X-ray Diffraction affirmed the crystalline nature of particles with a face centered cubic structure. The AgNPs exhibited the antimicrobial activity against Gram negative bacteria (Gram (-) Bacteria) and Gram positive bacteria (Gram (+) Bacteria) (Escherichia coli-MTCC-443, Staphylococcus aureus-MTCC-3381, Bacillus subtilis-MTCC No.10619, Proteus vulgaris-MTCC 1771, Klebsiella pneumonia-MTCC No 7028 and Bacillus megaterium-MTCC No. 2412). A. grandiflora may be used for the green synthesis of ultra-fine nanoparticles of silver for their antimicrobial activities.
\end{abstract}

Keywords: Silver nanoparticles; UV-Visible Spectroscopy; SEM; TEM; X-ray Diffraction

\section{Introduction}

Metal nanoparticles (Metal-Nps) have shown copious aspect in biomedical practice as they can be deliver as high-caliber, optically sound bioimaging agents, may be applied in biosensor tool for the early detection of several maladies [1,2]. These nanosize particles have also established in vivo encouraging effect as therapeutic agents $[3,4]$. The studies conducted in past few year, Metal-NPs have been improved for their antimicrobial activity and may locally destroy pathogenic organisms, without being toxic to the surrounding tissue [5-8]. Previously, there have been numerous reports on the green synthesis of metal nanoparticles [9-11] and AgNPs have their own importance among all. The chemical and physical properties of AgNPs are idiosyncratic and divergent from materials with the same chemical elements due to their small particle size $(<100 \mathrm{~nm})$. Of course, unique characteristics of AgNPs are firmly affected by their size and shape. The great surface/volume ratio of AgNPs clusters signal that most of their atom have position on the surface, are willing to rapid response. Preparations of AgNPs have their diverse properties and uses, like magnetic and optical polarizability [12], catalysis [12], antimicrobial [13] and electrical conductivity [14]. A. grandiflora is used as folk medicine in Himalayan region, India, may has potential reducing and capping properties and may produce much effective AgNPs compared to standard antibiotics. This study revealed the green synthesis of AgNPs by A. grandiflora and antimicrobial activity against Gram (-) Bacteria and Gram (+) Bacteria. The similar work also performed by Alizadeh $\mathrm{H}$ et al. [15] against Intramacrophage Brucella abortus 544 [15].

\section{Materials and Methods}

\section{Preparation of Extracts}

A. grandiflora (Glossy Abelia) belongs to Family Caprifoliaceaeis, a deciduous or semi-evergreen multi-stemmed shrub with rounded, spreading, or gracefully arching branches to $1-1.8 \mathrm{~m}$ tall.

The plant was acquired from University of Rajasthan, Jaipur and authenticated by National Institute of Ayurveda, Jaipur. The shade dried root of A. grandiflora were powdered by mechanical grinder and sieved to give particle size $50-150 \mathrm{~mm}$. An aqueous extract was prepared by boiling $30 \mathrm{gm}$ of dried powered of A. grandiflora root in $100 \mathrm{ml}$ of deionized water for 75 minutes. The extract was filtered using pal funnel with Whattman filter paper No 1 and final volume of filtrate adjusted to $100 \mathrm{ml}$ was stored at cool and dry place for further use.

\section{Synthesis of Silver AgNPs}

The stable AgNPs were synthesized by adding $3 \mathrm{ml}$ extract of $A$. grandiflora drop-wise in $1 \mathrm{mM}$ aqueous solution $(100 \mathrm{ml})$ of silver nitrate $\left(\mathrm{AgNO}_{3}\right)$. A change in color (dark brown) of solution within few minute gave signal of reduction of silver and the whole process completed in 45 minute [16]. The colloidal brownish solutions were centrifuged at 13,500 rpm for 15 minutes to separate the AgNPs as a pellet. After the formation of AgNPs colloidal solution, the mixture was recentrifuged at 13,500 rpm for 15 minutes. The pellets of AgNPs obtained, and washed more than 3 times by distilled water then dried and stored for further use.

\section{Characterization}

The Characterization of AgNPs was carried out by surface plasmon resonance band using a UV-Visible Spectroscopy 1800 of Shimadzu, Kyoto, Japan. Crystalline structure of AgNPs were analyzed by XRD6000 instrument of Shimadzu at $30 \mathrm{kV}$ and $20 \mathrm{~mA}$ current with $\mathrm{Cu}$ $\mathrm{Ka}\left(\mathrm{I}=1.54 \mathrm{~A}^{\circ}\right)$. All X-ray diffraction technicalities carried out under the exploratory circumstances in the angular extent $3^{\circ} \leq 2 \theta \leq 50^{\circ}$. Micrograph of AgNPs was obtained by scanning electron microscope of S-4500, Hitachi, Chiyoda-ku, Japan [17-19]. TEM micrograph of the

*Corresponding author: Nakuleshwar Dut Jasuja, Assistant Professor, School of Sciences, Suresh Gyan Vihar University, Jaipur-302017, Rajasthan, INDIA, Tel: +91-9414658277; E-mail: nakuljasuja@gmail.com

Received May 19, 2014; Accepted June 18, 2014; Published June 25, 2014

Citation: Sharma G, Jasuja ND, Rajgovind, Singhal P, Joshi SC (2014) Synthesis, Characterization and Antimicrobial Activity of Abelia grandiflora Assisted AgNPs. J Microb Biochem Technol 6: 274-278. doi:10.4172/1948-5948.1000156

Copyright: (c) 2014 Sharma G, et al. This is an open-access article distributed under the terms of the Creative Commons Attribution License, which permits unrestricted use, distribution, and reproduction in any medium, provided the original author and source are credited 
AgNPs was observed using the TEM instrument of JEOL JSM $100 \mathrm{cx}$. TEM device conducted at an increasing voltage of $200 \mathrm{kv}$.

\section{Determination of antibacterial activity of AgNPs}

The AgNPs and aqueous extract prepared by A. grandiflora were used to evaluate antimicrobial activity against Gram (-) and Gram (+) Bacteria (E. Coli-MTCC-443, S. aureus-MTCC-3381, B. subtilis-MTCC No.10619, P. vulgaris-MTCC 1771, K. pneumonia-MTCC No 7028 and B. megaterium-MTCC No. 2412) on MHA plates by agar well diffusion method [20]. The Minimum Inhibitory Concentration (MIC) method and Minimal Bactericidal Concentration (MBC) for all test bacterial strains were also determined.

\section{Results and Discussion}

The $\mathrm{AgNO}_{3}$ solution and fresh extract of A. grandiflora were colorless and Yellowish-brown respectively. After addition of $A$. grandiflora extracts to $\mathrm{AgNO}_{3}$ solution at 'magnetic stirring plate' the solution turned dark brown at $55^{\circ} \mathrm{C}$ confirmed formation of AgNPs. Interestingly, nanosilver were biosynthesized promptly within 45 minute claiming, speedy bioreducing approach (Figure 1).

AgNPs were ascertained by distinctive peak observed at $413 \mathrm{~nm} \lambda$ in the pilot range of $300-900 \mathrm{~nm} \lambda$. The specific silver surface plasmon resonance band were observed at 400-450 $\mathrm{nm} \lambda$, gave indication of smaller AgNPs formation $(<30 \mathrm{~nm}$ ) (Figure 2). The frequency and

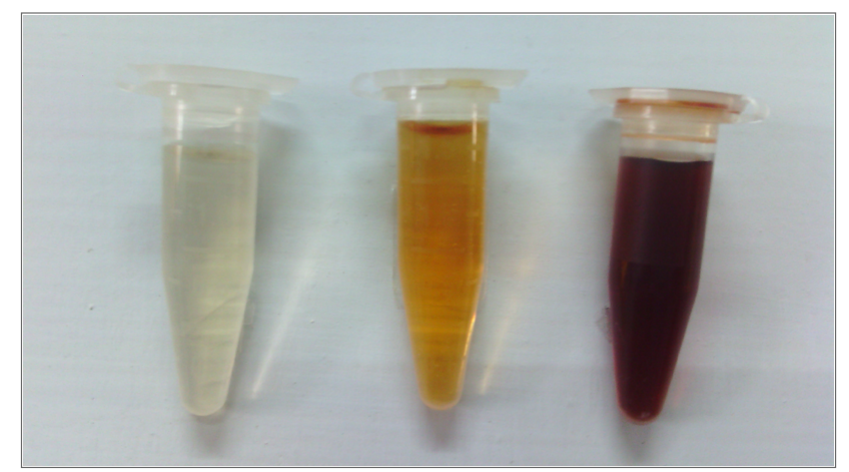

Figure 1: Optical Photograph of (a) $\mathrm{AgNO}_{3}$ solution, (b) A. grandiflora extract and (c) AgNPs solution.

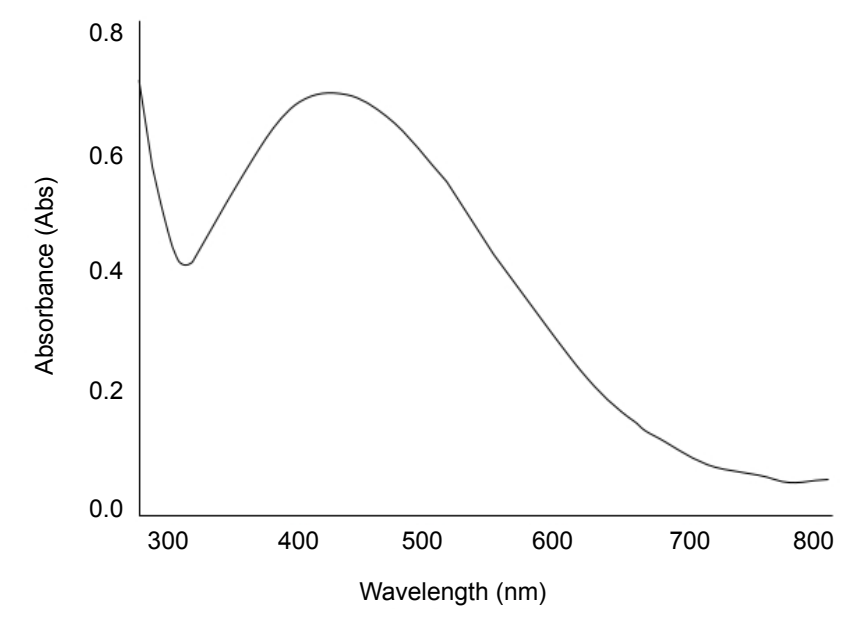

Figure 2: UV-Vis absorption spectra of AgNPs synthesized from $A$. grandiflora by reduction of silver ions to AgNPs.

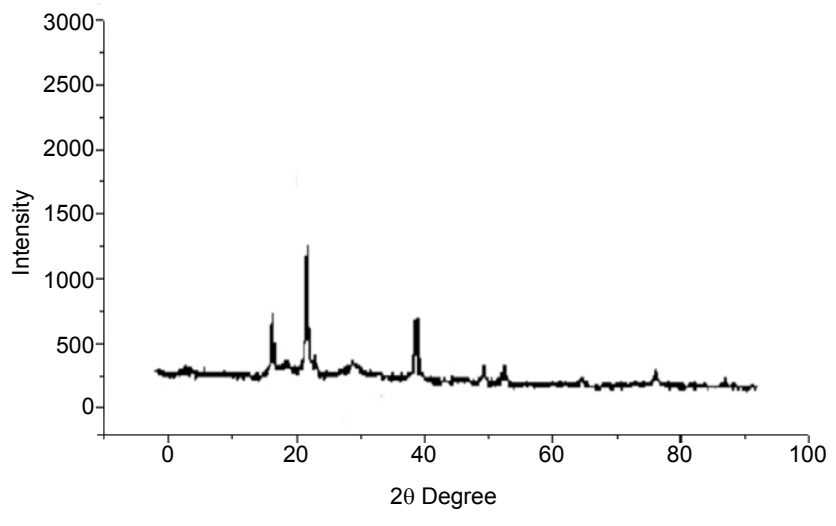

Figure 3: X-ray Diffraction Graph of AgNPs biosynthesized by A. grandiflora extract.
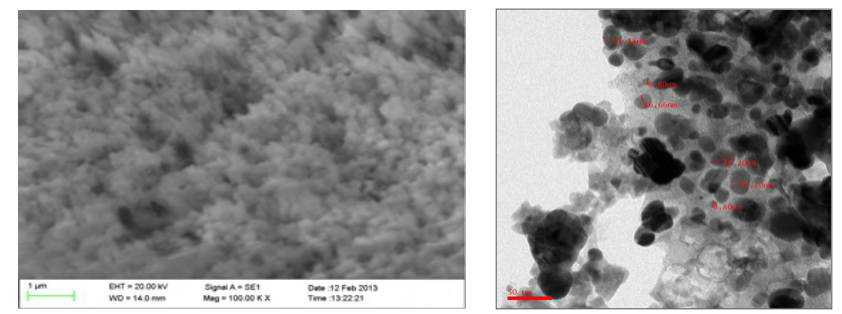

Figure 4: (A) The Scanning Electron Microscope images of AgNPs synthesized by $A$. grandiflora extract (B) TEM image of the AgNPs biosynthesized by $A$. grandiflora.

width of the surface plasmon absorption rely upon the size and shape of the AgNPs as well as on dielectric constant of the metal itself and the surrounding medium.

$\mathrm{X}$-ray diffraction is generally applied to certain chemical arrangement and crystal design of an objective; can be used for exposing the presence of AgNPs. The XRD patterns of resulted mixture gave signal that structure of AgNPs is face-centered cubic (fcc) and the AgNPs had a similar diffraction pattern. The X-ray Diffraction peaks observed in $2 \theta$ range of $30-80^{\circ}$ and indexed to 111,220 and 311 which confirms standard JCPDS file 04-0783 of silver are responsible for micrograph of the silver crystals (Figure 3).

The structural characteristic of biosynthesised AgNPs were studied by scanning electron microscope, using an instrument of Hitachi S-4500. The average size of AgNPs observed from 10-30 nm with inter-particle distance and the shape was found to be spherical. The aggregation of the nanoparticles indicates that they were in the direct contact, but stabilized by a capping agent (Figure 4A). In agreement with the UV-Visible Spectroscopic observations, the TEM images revealed Ag-nanocrystals were spherical in shape and in the range of 10-30 nm with considerable agglomeration (Figure 4B).

\section{Antimicrobial Activity of Ag Nanoparticles}

A turbid liquid sample of each bacterial strain with an OD of McFarland of $0.5\left(1 \times 10^{8} \mathrm{CFU} / \mathrm{mL}\right)$ was prepared in an isotonic $\mathrm{NaCl}$ $(0.85 \%)$ solution. Furthermore, this solution was diluted ten times $\left(1 \times 10^{7} \mathrm{CFU} / \mathrm{mL}\right)$ and used as inoculums. The agar well were filled with assorted concentration of AgNPs solution like $0.0025 \mathrm{mmol} / \mathrm{mL}$, $0.005 \mathrm{mmol} / \mathrm{mL}, 0.01 \mathrm{mmol} / \mathrm{mL}$ and $0.02 \mathrm{mmol} / \mathrm{mL}$ and Gentamicin procured by Hi-Media, Mumbai, was used as control. The zone of 
inhibition (ZOI) observed at the surrounding area of 'AgNPs solution filled agar well' after incubation at $37^{\circ} \mathrm{C}$ for 24 hours. The experiments were done triplicate and mean values of ZOI were reported [21].

The test microorganisms were found to be resistant for the aqueous extract of A. grandiflora but results indicated that AgNPs have strong dose-dependent action against both gram negative and gram positive microorganisms. All these microorganisms were found susceptible against the nanoparticles as growth of these microbes decreased with the increase in concentration of AgNPs (Figure 5).

The antibacterial effect of AgNPs against all six bacteria compared with the control, the diameters of ZOI $(\mathrm{mm})$ vary for all the test bacteria at different concentration level of AgNPs. It was revealed that $0.02 \mathrm{mmol} / \mathrm{mL}$ colloid solution of AgNPs showed $27 \mathrm{~mm}$ clear inhibitory zone against $E$. Coli after incubation for $24 \mathrm{~h}$ followed by B. megaterium $(26 \mathrm{~mm})$, then $24 \mathrm{~mm}$ for B. subtilis and $S$. aureus, minimum for $K$. pneumonia and $P$. vulgaris $(23 \mathrm{~mm}$ ) proposing that biosynthesized AgNPs have valuable antibacterial effect against Gram (+) than Gram (-) Bacteria (Table 1). The AgNPs showed remarkable antibacterial activities compared to other metal oxide nanoparticles like $\mathrm{ZnO}$ nanoparticles. The AgNPs synthesized in present work showed significant antimicrobial activity (i.e. $+15 \mathrm{~mm}$ and $+18 \mathrm{~mm}$ ) as compared to earlier studies on $\mathrm{ZnO}$ nanoparticles which were $24 \mathrm{~mm}$ and $27 \mathrm{~mm}$ against B. subtilis and E. coli [22].

The approaches of the growth-restrictive activities of AgNPs on microorganisms have not been clearly interpreted. One possibility of growth-restriction, may be chance of the generation of free radicals by AgNPs positioned at surface which may have been thrashed lipid membrane followed by destruction of microorganisms [23]. Few studies have explained that the $(+)$ charge on the $\mathrm{Ag}$ ion is crucial for its antibacterial effects through the electrostatic bondage among (-) charged cell membrane of pathogenic organism and $(+)$ charged nanoparticles [24-26]. In contrast, Sondi and Salopek-Sondi [27] suggested that the antibacterial effects of AgNPs on Gram (-) Bacteria was depend on the concentration of AgNPs, and closely related with the development of 'pits' on cell wall of bacteria. Further, these metallic
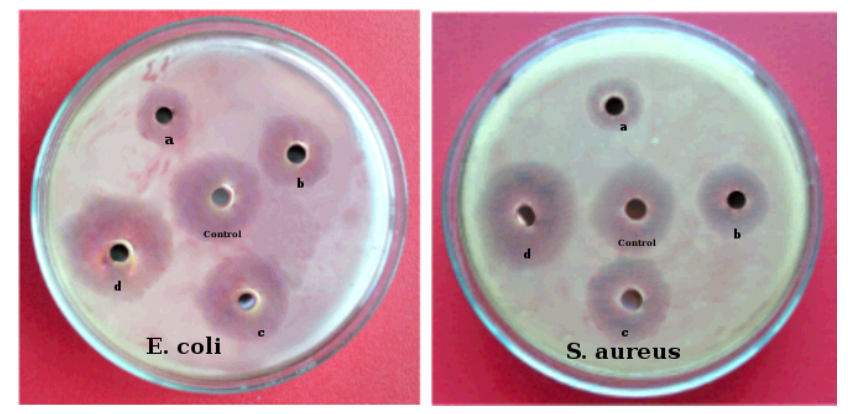

Figure 5: Zone of inhibition produced by Silver nanoparticles against both Gram-(+) and Gram-(-) bacterial strains. nanosize particles may attached or gathered on the surface of bacterial cell membrane disturb permeability and respiration which may cause cell cessation.

Moreover, silver nanoparticles may have multiple cellular targets that differ among all gram positive and gram negative bacterial cells which cover both (+) charged Ag ions and (-) charged other metallic ions [28].

\section{Minimum Inhibitory Concentration and Minimal Bactericidal Concentration}

The test tubes filled with $4 \mathrm{ml}$ of Nutrient Broth were prepared for bacterial culture, inoculated by loop-full of active cultures $\left(5 \times 10^{5}\right.$ $\mathrm{CFU} / \mathrm{mL}$ Conc.). Serial two-fold dilutions method was used to prepare different concentrations of AgNPs solution i.e. 100, 50, 25, 12.5, $6.25,3.12,1.56$ and $0.78 \mu \mathrm{g} / \mathrm{mL}$ followed by incubation for one day. The growth of bacterial culture was determined by observing OD on UV-Visible-1800 Spectroscopy (Shimadzu) at $600 \mathrm{~nm}$ after 24 $\mathrm{h}$ that represented the Minimum Inhibitory Concentration (MIC). All the experiments were carried out triplicate and identical course was applied to drive the MIC of the following controls: extract of A. grandiflora, Silver Nitrate solution, and standard antibiotics i.e. Gentamicin. Different concentrations i.e. 100 to $0.78 \mu \mathrm{g} / \mathrm{mL}$ for Silver Nitrate solution; 800 to $0.78 \mu \mathrm{g} / \mathrm{mL}$ for extract of A. grandiflora and 50 to $0.39 \mu \mathrm{g} / \mathrm{mL}$ for antibiotics have been used for MIC. Sterilized nutrient broth was used as the (-) control and inoculated broth was used as the $(+)$ control.

The MIC of AgNPs (MIC-AgNPs) against Gram negative and Gram positive bacteria are shown in Figure 6. The antimicrobial proficiency of the AgNPs represented by their MIC was $12.5 \mu \mathrm{g} / \mathrm{mL}$ for the S. aureus, and $3.12 \mu \mathrm{g} / \mathrm{mL}$ for the E. Coli. The MIC-AgNPs were comparatively less than that of the standard antibiotic, Gentamicin. Moreover, MIC-AgNPs were also significantly lower than solution of $\mathrm{AgNO}_{3}$ for all test bacteria. Such impressive effect of AgNPs may be due to interplay with the thiol group of L-cysteine protein residues that may force to enzymatic dysfunction [29] or the AgNPs may have galvanize the release of reactive oxygen species, which lead to destruction of DNA and protein of microorganism [30]. Furthermore, it is found that AgNPs have higher antibacterial activities (Comparatively higher MIC against $\operatorname{Gram}(+)$ bacteria) against $\operatorname{Gram}(-)$ bacteria may be due to the absence of thick layer of peptidoglycan in cell wall of Gram (-) bacteria [31,32].

The minimal concentration of AgNPs that kills $\geq 99.9 \%$ ( $3 \log$ ) of the bacteria (MBC) against Gram (-) Bacteria and Gram (+) Bacteria are shown in Figure 6. Here, the AgNPs have shown the similar pattern of minimal bactericidal concentration against all test bacteria as seen in MIC, were $25 \mu \mathrm{g} / \mathrm{mL}$ and $3.12 \mu \mathrm{g} / \mathrm{mL}$ for $S$. aureus and $E$. Coli, respectively. These concentrations represented the maximum and minimum $\mathrm{MBC}$ among all test Bacteria, are considerably lower than $\mathrm{AgNO}_{3}$ solution. The standard antibiotic, Gentamicin illustrated nearly similar value of MBC.

\begin{tabular}{|c|c|c|c|c|c|c|}
\hline \multirow{2}{*}{ Silver nanoparticle Concentration $(\mathrm{mmol} / \mathrm{mL})$} & \multicolumn{6}{|c|}{ Bacterial Sp (zone of inhibition $\mathrm{mm}$ ) } \\
\hline & B. subtilis & S. aureus & B. megaterium & E. Coli & K. pneumoniae & P. vulgaris \\
\hline 0.0025 & 11 & 14 & 13 & 13 & 12 & 11 \\
\hline 0.005 & 16 & 18 & 18 & 17 & 15 & 15 \\
\hline 0.01 & 21 & 23 & 22 & 22 & 19 & 20 \\
\hline 0.02 & 24 & 27 & 26 & 27 & 23 & 23 \\
\hline Control & 18 & 20 & 19 & 22 & 20 & 21 \\
\hline
\end{tabular}

Table 1: Antibacterial activity of Ag nanoparticles synthesized by extract of $A$. grandiflora. 
Citation: Sharma G, Jasuja ND, Rajgovind, Singhal P, Joshi SC (2014) Synthesis, Characterization and Antimicrobial Activity of Abelia grandiflora Assisted AgNPs. J Microb Biochem Technol 6: 274-278. doi:10.4172/1948-5948.1000156

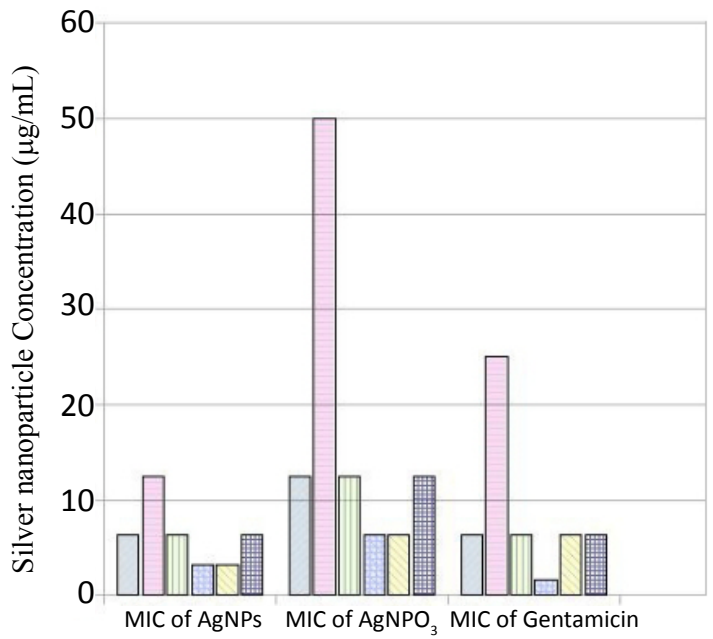

MIC

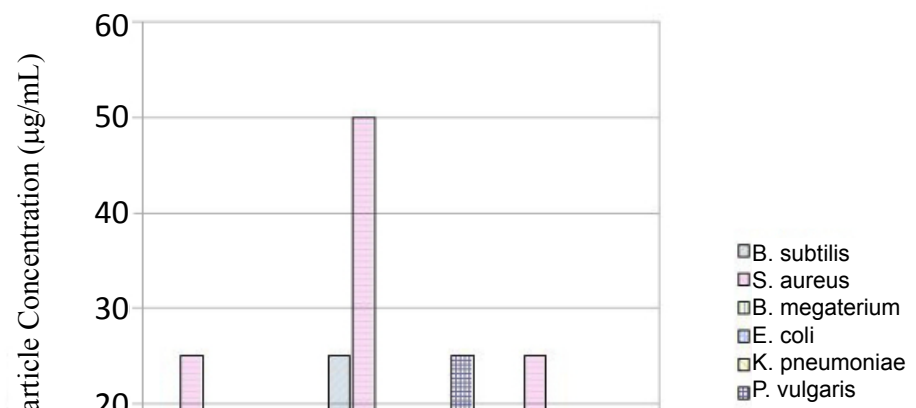

Figure 6: MIC and MBC Values of Nanosilver synthesized using extract of $A$. grandiflora.

\section{Conclusion}

It is revealed that $A$. grandiflora is a curiously effective reductant for Silver ions. This is a one pot reaction method, generating $10-30 \mathrm{~nm}$ size nanoparticles. The synthesis of AgNPs occurred within 45 minutes, without involvement of any toxic chemicals. It is acclaimed that Silver ions and Silver-based compounds have potent antimicrobial activity. Present study confers with the study of Azam et al. [33] revealed that antibacterial activities of AgNPs were significantly high as compared to silver nitrate and standard antibiotic may be due to their increased surface area. Therefore, these AgNPs can be used in low doses for antimicrobial treatment in comparison to standard antimicrobial agents.

\section{References}

1. De Jong WH, Borm PJ (2008) Drug delivery and nanoparticles:applications and hazards. Int J Nanomedicine 3: 133-149.

2. Lok CN, Ho CM, Chen R, He QY, Yu WY, et al. (2007) Silver nanoparticles: partial oxidation and antibacterial activities. J Biol Inorg Chem 12: 527-534.

3. Aguilar Z (2012) Nanomaterials for Medical Applications, USA

4. Alizadeha H, Saloutib M, Shapourib R (2013) Intramacrophage antimicrobial effect of silver nanoparticles against Brucella melitensis $16 \mathrm{M}$. Scientia Iranica 20:1035-1038.

5. Nagarajan S, Arumugam Kuppusamy K (2013) Extracellular synthesis of zinc oxide nanoparticle using seaweeds of gulf of Mannar, India. J Nanobiotechnology 11: 39.

6. Rai M, Yadav A, Gade A (2009) Silver nanoparticles as a new generation of antimicrobials. Biotechnol Adv 27: 76-83.

7. Gunalana S, Sivaraja R, Rajendranb V (2012) Green synthesized ZnO nanoparticles against bacterial and fungal pathogens. Natural Science: Materials International 22: 693-700

8. Verma VC, Kharwar RN, Gange AC (2010) Biosynthesis of antimicrobial silver nanoparticles by the endophytic fungus Aspergillus clavatus. Nanomedicine (Lond) 5: 33-40.

9. Pandey S, Goswami GK, Nanda KK (2013) Green synthesis of polysaccharide/ gold nanoparticle nanocomposite: an efficient ammonia sensor. Carbohydr Polym 94: 229-234.

10. Harne S, Sharma A, Dhaygude M, Joglekar S, Kodam K, et al. (2012) Novel route for rapid biosynthesis of copper nanoparticles using aqueous extract of
Calotropis procera L. latex and their cytotoxicity on tumor cells. Colloids Surf B Biointerfaces 15: 284-308.

11. Shiraishi Y, Toshima N (2000) Oxidation of ethylene catalyzed by colloida dispersions of poly(sodium acrylate)-protected silver nanoclusters. Colloids Surf A Physicochem Eng Asp 169: 59-66.11.

12. Sun T, Zhang Z, Xiao J, Chen C, Xiao F, et al. (2013) Facile and green synthesis of palladium nanoparticles-graphene-carbon nanotube material with high catalytic activity. Sci Rep 3: 2527.

13. Baker C, Pradhan A, Pakstis L, Pochan DJ, Shah SI (2005) Synthesis and antibacterial properties of silver nanoparticles. J Nanosci Nanotechnol 5: 244 249

14. Cao Y, Jin R, Mirkin CA (2001) DNA-modified core-shell Ag/Au nanoparticles. J Am Chem Soc 123: 7961-7962.

15. Alizadeh H, Salouti M, Shapouri M (2014) Bactericidal Effect of Silver Nanoparticles on Intramacrophage Brucella abortus 544. Jundishapur J Microbiol 7:e9039.

16. Huang ZY, Mills G, Hajek B (1993) Spontaneous formation of silver particles in basic 2-propanol. J Phys Chem 97: 11542-11550.

17. Holt JG, Krieg RN, Sneath PHA, Staley JT, Williams ST(1994) Bergey's manual of determinative bacteriology, 9th ed. Williams and Wilkins, Baltimore, pp. 2451-2508.

18. Gericke M, Pinches A (2006) Microbial production of gold nanoparticles. Gold Bull 39: 22-28.

19. Kalimuthu K, Suresh Babu R, Venkataraman D, Bilal M, Gurunathan S (2008) Biosynthesis of silver nanocrystals by Bacillus licheniformis. Colloids Surf $B$ Biointerfaces 65: 150-153.

20. Saha B, Bhattacharya J, Mukherjee M, Ghosh AK, Santra CR, et al. (2007) In Vitro Structural and Functional Evaluation of Gold Nanoparticles Conjugated Antibiotics. Nanoscale Res Lett 2: 614.

21. Tepe B, Donmez E, Unlu M, Candan F, Daferera D, et al. (2004) Antimicrobia and antioxidative activities of the essential oils and methanol extracts of Salvia cryptantha (Montbret et Aucher ex Benth.) and Salvia multicaulis (Vahl). Food Chem March 84: 519-525.

22. Meruvu H, Vangalapati M, Chippada SC, Bammidi SR (2011) Synthesis And Characterization of Zinc Oxide Nanoparticles And Its Antimicrobial Activity Against Bacillus Subtilis And Escherichia Coli. RASAYAN J Chem 4: 217-222.

23. Danilczuk M, Lund A, Sadlo J, Yamada H, Michalik J (2006) Conduction electron spin resonance of small silver particles. Spectrochim Acta A Mol Biomol Spectrosc 63: 189-191. 
Citation: Sharma G, Jasuja ND, Rajgovind, Singhal P, Joshi SC (2014) Synthesis, Characterization and Antimicrobial Activity of Abelia grandiflora Assisted AgNPs. J Microb Biochem Technol 6: 274-278. doi:10.4172/1948-5948.1000156

24. Hamouda T, Myc A, Donovan B, Shih A, Reuter JD, et al. (2000) A novel surfactant nanoemulsion with a unique non-irritant topical antimicrobial activity against bacteria, enveloped viruses and fungi. Microbiol Res 156: 1-7.

25. Dibrov P, Dzioba J, Gosink KK, Häse CC (2002) Chemiosmotic mechanism of antimicrobial activity of $\mathrm{Ag}(+)$ in Vibrio cholerae. Antimicrob Agents Chemother 46: $2668-2670$

26. Dragieva I, Stoeva S, Stoimenov P, Pavlikianov E, Klabunde K (1999) Complex formation in solutions for chemical synthesis of nanoscaled particles prepared by borohydride reduction process. Nanostruct Mater 12: 267-270.

27. Sondi I, Salopek-Sondi B (2004) Silver nanoparticles as antimicrobial agent: a case study on E. coli as a model for Gram-negative bacteria. J Colloid Interface Sci 275: 177-182.

28. Gordon O, Slenters TV, Brunetto PS, Villaruz AE, Sturdevant DE, et al. (2010) Silver coordination polymers for prevention of implant infection: thiol interaction, impact on respiratory chain enzymes, and hydroxyl radical induction. Antimicrob Agents Chemother 54: 4208-4218.
29. Ross ZM, O'Gara EA, Hill DJ, Sleightholme HV, Maslin DJ (2001) Antimicrobial properties of garlic oil against human enteric bacteria: evaluation of methodologies and comparisons with garlic oil sulfides and garlic powder. Appl Environ Microbiol 67: 475-480.

30. Hossain Z, Huq F (2002) Studies on the interaction between $\mathrm{Ag}(+)$ and DNA. J Inorg Biochem 91: 398-404.

31. Saravanan M, Vemu AK, Barik SK (2011) Rapid biosynthesis of silver nanoparticles from Bacillus megaterium (NCIM 2326) and their antibacteria activity on multi drug resistant clinical pathogens. Colloids Surf B Biointerfaces 88: 325-331.

32. Kim SH, Lee HS, Ryu DS, Choi SJ, Lee DS (2011) Antibacterial activity of silver-nanoparticles against Staphylococcus aureus and Escherichia coli. Korean J Microbiol Biotechnol 39: 77-85.

33. Azam A, Ahmed AS, Oves, M, Khan MS, Habib SS, Memic A (2012)Antimicrobial activity of metal oxide nanoparticles against Gram-positive and Gram-negative bacteria: a comparative study. Int J Nanomedicine 7: 6003-6009. 